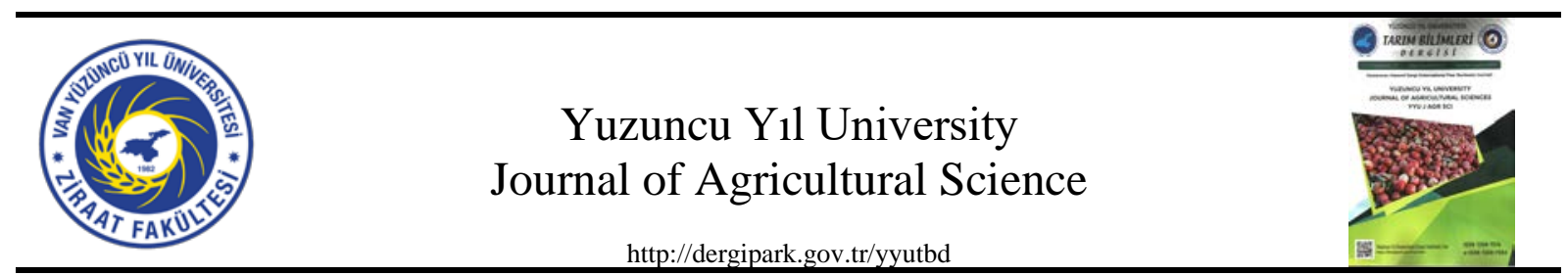

Research Article (Araştırma Makalesi)

Scanning Morphological Traits of Orchardgrass (Dactylis glomerata L.) Genotypes in the Natural Rangelands of Eastern Anatolia

\author{
Ahmad NABHAN ${ }^{* 1}$, Ösmetullah ARVAS², Abdulkarim LAKMES ${ }^{3}$ \\ ${ }^{1}$ Van Yüzüncü Y1l University, Institute of Natural and Applied Sciences Van, Turkey \\ ${ }^{2}$ Van Yüzüncü Y1l University, Department of Field Crops, Van, Turkey \\ ${ }^{3}$ Harran University, Department of Field Crops, Sanliurfa, Turkey \\ ${ }^{1}$ https://orcid.org/0000-0002-8125-8913 ${ }^{2}$ https://orcid.org/0000-0001-8713-2388 ${ }^{3}$ https://orcid.org/0000-0002-8167-7085 \\ *Corresponding author e-mail: ahmadnbhan1982@gmail.com
}

\section{Article Info}

Received: 12.10 .2020

Accepted: 08.01.2021

Online Published 30.03.2021

DOI: 10.29133/yyutbd.809169

Keywords

Dactylis glomerata,

Fodder crop,

Morphological character.

\begin{abstract}
Orchardgrass (Dactylis glomerata L.) is one of the essential foraging species which is used as a cool-season persistent and perennial forage grass. This research was carried out during the 2019 growing season in the Eastern Anatolia region in Turkey. The aim of our research was to study the morphologic characteristics of natural Orchardgrass and to assess the genetic diversity of collected genotypes to determine the best genotypes available for future breeding programs. In each location, the seeds of Orchardgrass were randomly collected and then were planted in the greenhouse. After germination, the Orchardgrass seedlings were transferred from the greenhouse to the field. Genotypes were investigated regarding plant height, flag leaf length, flag leaf width, number of nodes per plant, length of the upper internode. The results of this study showed highly significant differences between genotypes for studied traits. Furthermore, our results showed that the morphological traits studied (plant height, flag leaf length, flag leaf width, node number per plant, and length of the upper internode) had the following respectively ranges $(47.43-77.57 \mathrm{~cm}$, 9.00-15.57 cm, 4.21- 6.93mm, $2.14-3.00$, 9.64-17.57 cm, respectively). The analysis indicated that there was a positive significant correlation among the most morphological traits studied. The cluster analysis showed that the genotypes of the fourth group, (H5, M75 and A121) had the best genotypes for morphological traits studied. These genotypes can be used in future breeding programs.
\end{abstract}

\title{
Doğu Anadolu'nun Doğal Çayır ve Meralarında Yayılış Gösteren Domuz Ayrı̆̆ı (Dactylis glomerata L.) Genotiplerinin Bazı Morfolojik Özelliklerin Taranması
}

\section{Makale Bilgileri}

Geliş: 12.10 .2020

Kabul: 08.01.2021

Online Yayınlanma 30.03.2021

DOI: 10.29133/yyutbd.809169

\section{Anahtar kelimeler}

Dactylis glomerata, Örnek olarak; Morfolojik karakter. Yem bitkisi
Öz: Domuz ayrığı (Dactylis glomerata L.), serin iklimlerde doğal olarak yayılış gösteren çok y1llık bir yem bitkisidir. Bu çalışma 2019 y1lı vejetasyon döneminde Doğu Anadolu Bölgesi’nde yürütülmüştür. Çalışma, bölgemizin çayır ve meralarında doğal olarak yetişen Domuz ayrığg (Dactylis glomerata L.) genotiplerinin morfolojik özelliklerini belirlemek amaciyla yürütülmüştür. Yapılması planlanan ıslah çalışmaları için en uygun Domuz ayrığı (Dactylis glomerata L.) genotipleri belirlenmeye çalışılmıştır. Her lokasyondaki bitkilerden şansa bağlı olarak toplanan tohumlar serada ekilmiştir. Çıkış yapan bitkiler tarlaya şaşırtılmıştır. Genotiplerin bitki boyu, bayrak yaprak boyu, bayrak yaprak eni, üst boğumlar arası uzunluğu ve bitki başına boğum sayısı incelenmiştir. İncelenen özellikler açısından genotipler arasında önemli farklılıkların olduğu belirlenmiştir. Bitki boyu, bayrak yaprak boyu, bayrak 
yaprak eni, boğum sayısı ve üst boğumlar arası uzunluğu sırasıyla $47.43-77.57$ cm, 9.00-15.57 cm, 4.21- 6.93mm, $2.14-3.00$ ve 9.64-17.57 cm olarak ölçülmüştür. İncelenen morfolojik özellikler arasında pozitif ve anlamlı korelasyon belirlenmiştir. Kümeleme analizinde dört grup oluşmuş, H5, M75 ve A121 morfolojik olarak en üstün genotipler olarak belirlenmiş ve sslah materyali olarak değerlendirilebileceği sonucuna varılmıştır.

\section{Introduction}

Orchardgrass (Dactylis glomerata L.) is a widespread, highly cross-pollinated, cool-season, perennial grass, which is strongly adaptive to several environmental conditions (Madesis et al., 2014). The genus Dactylis is an essential forage crop, with a large geographical distribution in temperate zone. This genus includes one species, Dactylis glomerata; this species encompasses many subspecies whose traits have not been completely characterized (Zhao and Cheng, 2016) .

Meadows and pastures are the most important gene sources in Turkey. Early grazing and overgrazing have affected negatively the botanical composition of these areas; consequently, their production and biodiversity have decreased. Fodder crops grown in agricultural fields and natural ranges and pastures constitute the most important inputs in the production of animal food, which is of great importance in human nutrition. In addition, fodder crops grown in agricultural fields produce organic matter that benefits poor soil and other field crops (Mut and Ayan, 2008).

Natural pastures are important genetic resources in the development of new plant species and such lands constitute almost one-fifth of Turkey's surface area. In order to provide adequate and cheap animal products through securing quality fodders for our animals, it is necessary to improve our pastures and to forage crop cultivation within the field of agriculture (Uysal et al., 2015). For this reason, through breeding programs, it is necessary to develop types of high-quality fodder plants that can be cultivated within agricultural fields or in different environmental sites (Jiang et al., 2013).

The Eastern Anatolia region of Turkey is home to many rangelands and forage crop species (Aygün et al., 2009). Furthermore, it has 35\% of total pasture lands, which are considered a gene source of various plants used in pasture and meadows of Turkey (Uysal et al., 2015). It is one of the richest countries in the world in terms of a variety of plants. The most important reasons for this are: climate differences, topographic diversity, geological diversity, diversity of water sources, and altitude differences (Erdoğdu et al., 2018). Although it has excellent potential concerning both the rehabilitation of natural rangelands and the establishment of artificial pastures, studies on the possibilities of cultivation of these genotypes are almost nonexistent. Thus, there is a need for characterization of those species widely found in the natural rangelands of the region. This is of importance regarding the sustainability and success of new variety development and rangeland rehabilitation studies since these lines and genotypes can easily be cultivated, and they can prove high and sustainable yield level especially under the influence of the East Anatolian climate due to natural selection over thousands of years.

The aim of this research was to study the morphologic characteristics of natural orchardgrass and to assess the genetic diversity of collected genotypes from 20 different geographically locations in Eastern Anatolia to determine the best genotypes available for future breeding programs.

\section{Material and Methods}

\subsection{Climate characters}

The research was carried out in the experimental field and greenhouse of Van Yüzüncü Y1l University Faculty of Agriculture, Field Crops Department. Climate factors of the experiment site recorded during the growing season of (2019); Monthly total rainfall (mm), monthly average temperature $\left(\mathrm{C}^{\circ}\right)$ and long years average values were given in (Table 1) (Anonymous, 2019). 
Table 1. Climatic information for the studied area (Temperature $\left(\mathrm{C}^{\circ}\right)$ and rainfall $(\mathrm{mm})$ for the studied area (Van city) during the growing season and through long term) (Anonymous, 2019)

\begin{tabular}{|c|c|c|c|c|c|c|c|c|}
\hline \multirow{3}{*}{ Month } & \multicolumn{4}{|c|}{ During growing season in 2019} & \multicolumn{4}{|c|}{ Long term $\left(\mathrm{C}^{\circ}\right)$} \\
\hline & \multicolumn{3}{|c|}{ Temperature $\left(\mathrm{C}^{\circ}\right)$} & \multirow{2}{*}{$\begin{array}{l}\text { Rainfall } \\
(\mathrm{mm})\end{array}$} & \multicolumn{3}{|c|}{ Temperature $\left(\mathrm{C}^{\circ}\right)$} & \multirow{2}{*}{$\begin{array}{l}\text { Rainfall } \\
(\mathrm{mm})\end{array}$} \\
\hline & Max & Min & Average & & Max & Min & Average & \\
\hline March & 6.5 & -2.8 & 1.5 & 46.4 & 6.8 & -2.1 & 1.9 & 48.9 \\
\hline April & 12.8 & 2.5 & 7.6 & 55.6 & 12.9 & 3.3 & 8.1 & 53.2 \\
\hline May & 18.5 & 7.0 & 13.1 & 45.9 & 18.2 & 7.6 & 13.2 & 48.3 \\
\hline June & 23.9 & 10.8 & 18.2 & 18.6 & 23.9 & 11.7 & 18.6 & 17.9 \\
\hline July & 28.2 & 14.6 & 22.2 & 6.2 & 28.0 & 15.5 & 22.5 & 6.2 \\
\hline August & 28.4 & 14.6 & 22.1 & 5.8 & 28.1 & 15.4 & 22.1 & 4.2 \\
\hline September & 24.3 & 10.7 & 17.8 & 15.8 & 24.1 & 11.5 & 17.5 & 14.0 \\
\hline
\end{tabular}

\subsection{Materials}

The seeds of Dactylis glomerata L. were randomly collected from 20 different locations which are naturally spread in Flora of the Eastern Anatolia Region of Turkey during July and August in 2018. (Table 2)

Table 2- The genotypes used in the study and geographical regions where they were collected

\begin{tabular}{|c|c|c|c|c|c|}
\hline N0 & Genotype & Location & Latitude & Longitude & Altitude (m) \\
\hline 1 & $\mathrm{H} 2$ & Hakkari - Merzan & $37^{\circ} 33.639^{\prime}$ & $043^{\circ} 41.629^{\prime}$ & 2166 \\
\hline 2 & H3 & Hakkari - Ademan & $37^{\circ} 33.502^{\prime}$ & $0433^{\circ 40417}$ & 2543 \\
\hline 3 & H5 & Hakkari - Kamışlı köyü & $37^{\circ} 34.259^{\prime}$ & 043 $32195^{\prime}$ & 1717 \\
\hline 4 & H6 & Hakkari - Cevizdibi köyü & $37^{\circ} 32.511^{\prime}$ & 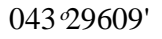 & 1575 \\
\hline 5 & H21 & Hakkari- Durkankaya & $37^{\circ} 37.980^{\prime}$ & $0433^{\circ} 37165^{\prime}$ & 2999 \\
\hline 6 & H27 & Hakkari - Durkankaya & $37^{\circ} 37.648^{\prime}$ & 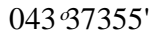 & 3011 \\
\hline 7 & H41 & Hakkari - Merkez & $37^{\circ} 43.755^{\prime}$ & $0435^{\prime} 8169 '$ & 2347 \\
\hline 8 & M74 & Muş-Varto & $39^{\circ} 09.297^{\prime}$ & $041^{\circ 4} 1311^{\prime}$ & 2073 \\
\hline 9 & M75 & Muş-Varto & $39^{\circ} 09.489^{\prime}$ & $041^{\circ 4} 1010^{\prime}$ & 2088 \\
\hline 10 & M81 & Muş- Merkez & 38 '35.980' & $041^{\circ} 33786^{\prime}$ & 1438 \\
\hline 11 & M115 & Muş-Bulanık & $38^{\circ 49314^{\prime}}$ & $041^{\circ} 72540^{\prime}$ & 1532 \\
\hline 12 & A121 & Iğdır -Patnos & 39 94116' & $04254890 '$ & 1637 \\
\hline 13 & V141 & Van-Erçiş & $3905549 '$ & $0433^{\circ} 3911^{\prime}$ & 1750 \\
\hline 14 & R163 & Eğdır-Merkez & 38 49922' & $043 \% 40526^{\prime}$ & 1725 \\
\hline 15 & V189 & Van-Kampüs & $3857119^{\prime}$ & 04328818' & 1665 \\
\hline 16 & V202 & Van-Bostanci & 38 '52552' & $043^{\circ} 44658^{\prime}$ & 1688 \\
\hline 17 & K240 & Kars-Dağpınar & $40^{\circ} 47510^{\prime}$ & $0433^{\circ} 31681^{\prime}$ & 2119 \\
\hline 18 & V241 & Van- Gevaş & $38^{\circ 29934^{\prime}}$ & 043 10640' & 1750 \\
\hline 19 & B261 & Bitlis-Merkez & $38^{\circ 42022^{\prime}}$ & $04^{\prime 21235} 4^{\prime}$ & 1558 \\
\hline 20 & E283 & Erzrum-Merkez- Saltuklu & $3990226^{\prime}$ & $041^{997740^{\prime}}$ & 1870 \\
\hline
\end{tabular}

The seeds of plants in each location were mixed together, and then the seeds of each location were planted in greenhouse in pots with a height of $22.5 \mathrm{~cm}$, a base diameter of $7.5 \mathrm{~cm}$ and a top diameter of $10 \mathrm{~cm}$, in each pot. After completion of germination and growth, the seedlings in each genotype were transferred into the field and were planted in seven replications by randomized complete block design (RCBD). In the field, plants were planted by lines, with spacing of $30 * 50 \mathrm{~cm}$.

The observations were obtained from plants of each line with during the season of 2019. N, and $\mathrm{P}_{2} \mathrm{O}_{5}$ fertilizer as well as organic fertilizer (animal manure) were applied and mixed into the surface of soil. In addition, the irrigation for seedlings was carried out regularly. Moreover, weed control was carried out by hoeing.

In each line, 7 plants of each genotype randomly were sampled for five morphological characteristics: Plant height (The distance between soil surface and portion of the spike $(\mathrm{cm})$ ), Flag leaf length (Mature leaf length $(\mathrm{cm})$ ), Flag leaf width (Mature leaf width $(\mathrm{mm})$ ), node number per plant (node number per plant), length of the upper internode (the length of the node of top $(\mathrm{cm})$ ). (Ozkose and Tamkoc, 2014) 


\subsection{Statistical Analysis of Morphological Data}

Statistical analysis was performed with Microsoft Excel and SPSS v23 and GenStat v12 software. A descriptive summary of morphological traits was calculated for each trait and means were compared by ANOVA followed by LSD tests to investigate further the differences between these morphological traits. Histograms were constructed to show the frequency distribution of morphological traits studied. UPGMA dendrogram cluster analysis was drawn for grouping the collected genotypes studied. Correlation tests were performed between morphological traits studied.

\section{Results}

\subsection{Morphological traits}

Plant height: According to analysis of variance for plant height, there were highly significant $(p<0.01)$ differences between genotypes. The mean of plant height for 20 genotypes studied was $59.10 \mathrm{~cm}$ (Table. 3). The highest genotype was M 75 with (77.57) $\mathrm{cm}$, whereas the lowest plant height genotype was $\mathrm{H} 27(47.43 \mathrm{~cm})$ (Table 4). Coefficient of variation (CV\%) was 12.5\% (Table.3). The frequency distribution of plant height showed that the vast majority of genotypes were between 55 and $65 \mathrm{~cm}$ (Figure.1).

Flag leaf length: The variance analysis for flag leaf length $(\mathrm{p}<0.01)$ indicated that highly significant differences between genotypes. The average of the flag leaf length of Orchardgrass genotypes was $11.62 \mathrm{~cm}$ (Table. 3). Genotype M75 $(15.57 \mathrm{~cm})$ was the longest flag leaf length, while genotype V241 $(9.00 \mathrm{~cm})$ had the shortest flag leaf length (Table .4). Coefficient of variation (CV\%) was $20.5 \%$. (Table .3). Frequency distribution of flag leaf length showed that the most of genotypes were between 10 and $12 \mathrm{~cm}$ (Figure.1).

Flag leaf width: According to analysis of variance for flag leaf width $(\mathrm{p}<0.01)$, there were highly significant differences between genotypes. The average of the flag leaf width of Orchardgrass genotypes was $5.62 \mathrm{~mm}$ (Table.3). Genotype A121 $(6.93 \mathrm{~mm})$ had the highest flag leaf width, while genotype E288 (4.21 mm) had the lowest flag leaf width (Table 4). Coefficient of variation (CV \%) for this trait was $14.3 \%$ (Table.3). Frequency distribution of flag leaf width showed that the most of genotypes were between 5.00 and $6.00 \mathrm{~mm}$ (Figure.1).

Node number per plant: According to analysis of variance for, there were highly significant differences between genotypes for node number/plant $(\mathrm{p}<0.01)$. The average node number/plant for Orchardgrass genotypes was 2.79 (Table. 3). Genotypes H5, M75, M115, K240, V189, V202 were the largest node number/plant 3.00, while the smallest node number/plant were 2.14 at H27 genotype (Table 4). The CV\% for this trait was $13.0 \%$ (Table.3). Frequency distribution of average node number per plant showed that the most of genotypes were between 2.50 and 3.00 (Figure.1).

Length of the upper internode: Variance analysis for length of the upper internode indicated highly significant differences between genotypes $(\mathrm{p}<0.01)$. The mean of length of the upper internode of Orchardgrass genotypes was found as $13.19 \mathrm{~cm}$ (Table.3). Genotype M75 and V189 $(17.57 \mathrm{~cm})$ was the highest length of the upper internode while genotype $\mathrm{H3}(9.64 \mathrm{~cm})$ had the lowest value for this trait (Table 4). The CV\% for this trait was 17.4\% (Table.3). Frequency distribution of length of the upper internode showed that the most of genotypes were between 11.00 and $13.00 \mathrm{~cm}$ (Figure.1).

Table .3. Summary of statistical values observations for some morphological traits of 20 Orchardgrass genotypes

\begin{tabular}{|c|c|c|c|c|c|c|c|}
\hline & Minimum & Maximum & Mean & Mean Std. Error & Std. Deviation & Variance & $\mathrm{CV} \%$ \\
\hline Plant height (cm) & 47.43 & 77.57 & 59.10 & 0.97 & 11.51 & 132.49 & 12.5 \\
\hline Flag leaf length $(\mathrm{cm})$ & 9.00 & 15.57 & 11.62 & 0.24 & 2.89 & 8.33 & 20.50 \\
\hline Flag leaf width (mm) & 4.21 & 6.93 & 5.62 & 0.09 & 1.017 & 1.03 & 14.30 \\
\hline Node number per plant & 2.14 & 3.00 & 2.79 & 0.03 & 0.41 & 0.17 & 13.00 \\
\hline Length of the upper internode $(\mathrm{cm}) \mathrm{s}$ & 9.64 & 17.57 & 13.19 & 0.27 & 3.18 & 10.10 & 17.40 \\
\hline
\end{tabular}

$\mathrm{CV}=$ Coefficient of variation 
Table .4. Significant differences for morphological traits of Orchardgrass

\begin{tabular}{|c|c|c|c|c|c|c|c|c|c|c|}
\hline 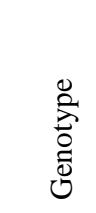 & 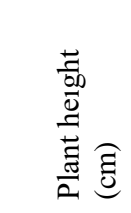 & 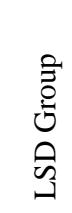 & 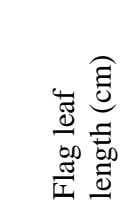 & 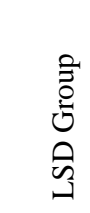 & 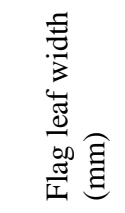 & $\begin{array}{l}\text { בे } \\
\text { 苟 } \\
\text { की }\end{array}$ & 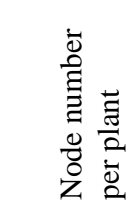 & 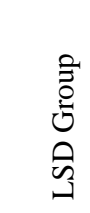 & 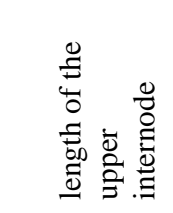 & 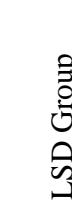 \\
\hline $\mathrm{H} 2$ & 55.43 & F-I & 10.79 & E-G & 5.50 & C-E & 2.86 & A-B & 11.36 & D-G \\
\hline H3 & 48.57 & H-I & 11.39 & D-G & 5.79 & B-E & 2.86 & A-B & 9.64 & G \\
\hline H5 & 72.29 & A-C & 14.86 & A-B & 6.50 & A-B & 3 & A & 16.36 & A-B \\
\hline H6 & 49.57 & H-I & 12.14 & C-E & 5.93 & B-D & 2.71 & A-B & 11.00 & E-G \\
\hline H21 & 55.57 & F-H & 10.71 & E-G & 6.43 & A-B & 2.86 & A-B & 13.00 & C-E \\
\hline H27 & 47.43 & I & 10.29 & E-G & 5.86 & B-E & 2.14 & $\mathrm{C}$ & 10.17 & F-G \\
\hline H41 & 54.71 & G-I & 11.86 & D-F & 5.36 & C-E & 2.57 & B & 11.50 & D-G \\
\hline M74 & 48.43 & H-I & 10.29 & E-G & 4.50 & F-G & 2.86 & A-B & 10.71 & E-G \\
\hline M75 & 77.57 & A & 15.57 & A & 6.57 & A-B & 3.00 & A & 17.57 & A \\
\hline M81 & 55.86 & F-H & 12.36 & B-E & 5.93 & B-D & 2.71 & A-B & 12.57 & C-F \\
\hline M115 & 63.14 & D-F & 10.07 & E-G & 5.86 & B-E & 3.00 & A & 12.43 & C-F \\
\hline A121 & 76.29 & A-B & 14.64 & A-C & 6.93 & A & 2.86 & A-B & 17.21 & A \\
\hline V141 & 62.71 & $D-G$ & 9.86 & E-G & 5.36 & C-E & 2.71 & A-B & 14.50 & B-C \\
\hline R163 & 69.00 & B-D & 10.93 & $D-G$ & 5.36 & C-E & 2.57 & B & 14.21 & B-C \\
\hline V189 & 67.00 & C-E & 11.86 & D-F & 5.29 & D-E & 3.00 & A & 17.57 & A \\
\hline V202 & 58.43 & F-G & 12.21 & C-E & 5.07 & E-F & 3.00 & A & 13.69 & C-D \\
\hline K240 & 57.71 & F-G & 10.93 & D-G & 5.36 & C-E & 3.00 & A & 12.43 & C-F \\
\hline V241 & 48.00 & H-I & 9.00 & G & 4.47 & F-G & 2.71 & A-B & 13.50 & C-D \\
\hline B261 & 59.00 & E-G & 13.39 & A-D & 6.14 & A-C & 2.86 & A-B & 12.93 & C-E \\
\hline E283 & 55.29 & F-I & 9.36 & F-G & 4.21 & G & 2.57 & B & 11.50 & $\mathrm{D}-\mathrm{G}$ \\
\hline \multicolumn{3}{|c|}{ LSD $0.05=7.85$} & \multicolumn{2}{|c|}{ LSD $0.05=2.50$} & \multicolumn{2}{|c|}{ LSD $0.05=0.43$} & \multicolumn{2}{|c|}{ LSD $0.05=0.39$} & \multicolumn{2}{|c|}{ LSD $0.05=2.42$} \\
\hline
\end{tabular}



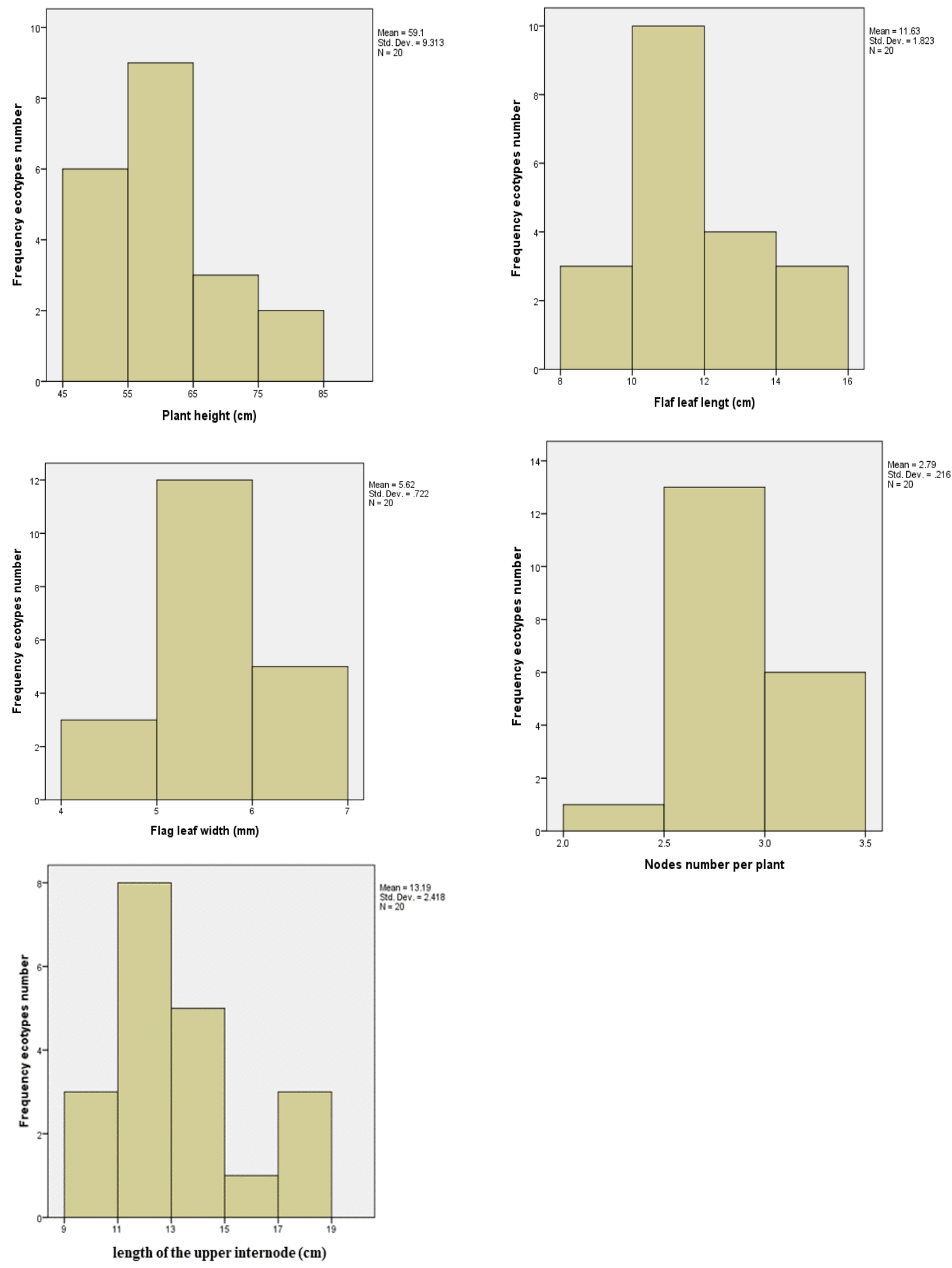

Figure 1. Frequency distribution of morphological traits of Orchardgrass genotypes.

\subsection{Cluster analysis}

UPGMA dendrogram (Figure 2.) was drawn and evaluated as four groups to present the relationships among genotypes. Cluster analysis is usually used for grouping the collected germplasm.

Orchardgrass genotypes were divided into 4 groups based on cluster analysis. The genotypes H5, M75 and A121 were placed into the forth group and they had the highest value and mean for all morphological studied traits (Table 5.). However, the genotype H27 was placed into the second group 
and this genotype had the lowest value and mean for plant height, and node number per plant, as well as the third group consisting of M74, V241, and E283 genotypes which having the lowest value and mean for flag leaf length and flag leaf width, while the first group consisting of H2, H3, H6, H21, H41, M74, M115, V141, V163, V189, V202, K240 and B261 genotypes. In general the first group had the medium values for all studied traits; however M115, V142, R163 and V189 had high plant height, while the B261 had high flag leaf length and width, for node number per plant V189 and V 202 had high value, as well as V 189 had highest value for Length of the upper internode.

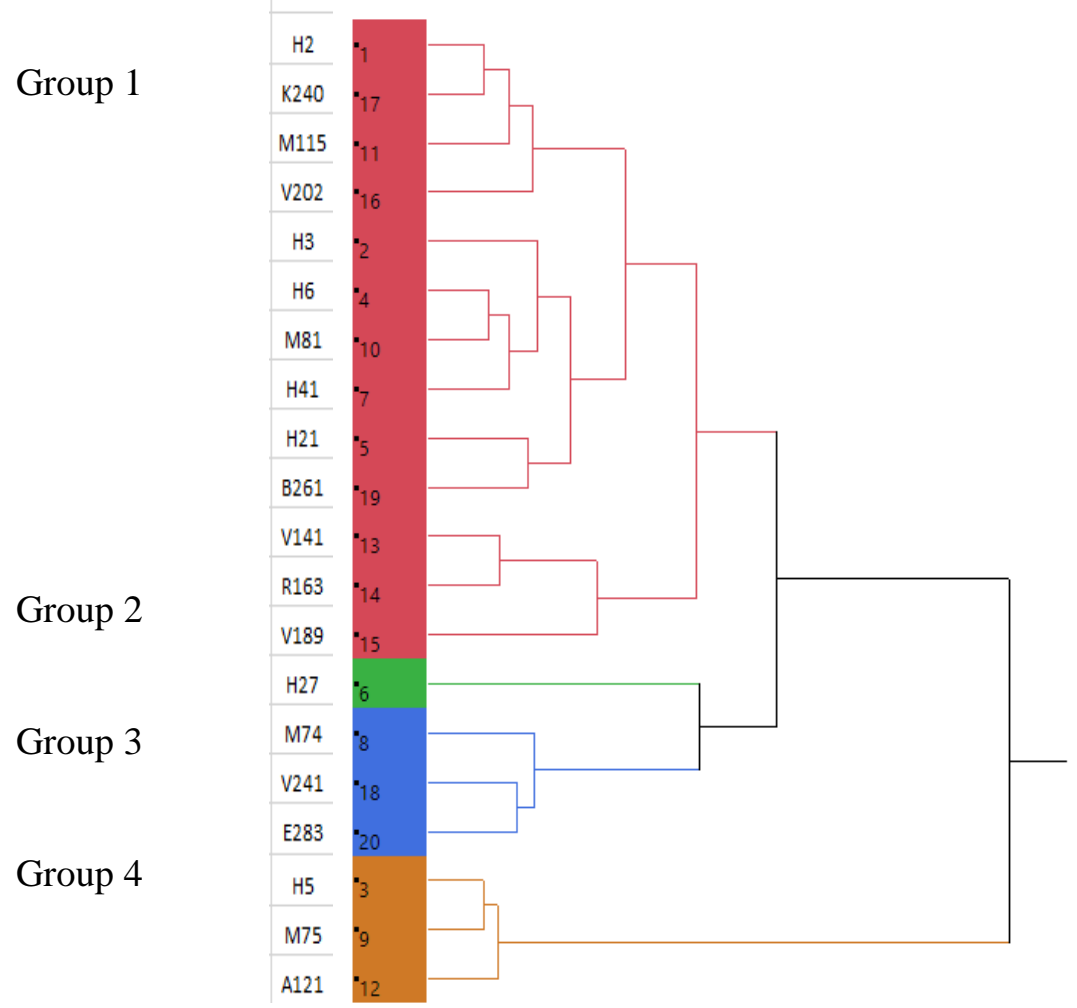

Figure 2. UPGMA dendrogram of some morphological traits of the studied genotypes for 20 Orchardgrass genotypes.

Table 5. The mean of morphological traits in each cluster group

\begin{tabular}{|c|c|c|c|c|c|}
\hline $\begin{array}{l}\text { Cluster } \\
\text { group }\end{array}$ & Plant height $(\mathrm{cm})$ & Flag leaf length $(\mathrm{cm})$ & $\begin{array}{l}\text { Flag leaf width } \\
(\mathrm{mm})\end{array}$ & Node number per plant & $\begin{array}{l}\text { Length of the upper } \\
\text { internode }(\mathrm{cm})\end{array}$ \\
\hline Group 1 & 58.21 & 11.42 & 5.64 & 2.82 & 12.83 \\
\hline Group 2 & 47.43 & 10.29 & 5.86 & 2.14 & 10.17 \\
\hline Group 3 & 50.57 & 9.55 & 4.39 & 2.71 & 11.90 \\
\hline Group 4 & 75.38 & 15.02 & 6.67 & 2.95 & 17.05 \\
\hline
\end{tabular}

\subsection{Correlation}

The positive significant correlation was between all traits studied except node number per plant with flag leaf length and flag leaf width was not significant. (Table .6).

Table 6. correlations between studied morphological trait for Orchardgrass

\begin{tabular}{|c|c|c|c|c|}
\hline & Flag leaf length (cm) & Flag leaf width (mm) & Node number per plant & $\begin{array}{l}\text { Length of the upper } \\
\text { internode }(\mathrm{cm})\end{array}$ \\
\hline Plant height (cm) & $0.47 * *$ & $0.37 * *$ & $0.21 *$ & $0.75^{* *}$ \\
\hline Flag leaf length $(\mathrm{cm})$ & 1 & $0.58 * *$ & 0.11 & $0.34 * *$ \\
\hline Flag leaf width (mm) & & 1 & 0.10 & $0.25^{* *}$ \\
\hline Node number per plant & & & 1 & $0.17 *$ \\
\hline
\end{tabular}

*Correlation is significant at the 0.05 level.

** Correlation is significant at the 0.01 level. 


\section{Discussion and Conclusion}

Prior studies have studied the genetic diversity of Dactylis glomerata $L$ by assessing many genotypes in many different geographic locations , and these studies have found there were significant differences among the studied genotypes for the morphological traits ( Sagsoz et al., 1996; Garcia and Lindner, 1998; Sahuquillo and Lumaret, 1999; Tuna et al., 2004; Mut and Ayan, 2008; Peng et al., 2008; Ayan et al., 2010; Uysal et al., 2015).

In the current study, the genotypes of Dactylis glomerata were collected from the different geographical locations of the Eastern Anatolia region and then planted in the same location to determine the genotypic features of these plants by eliminating the effects of environmental factors by the current study. This method was consistent with previous studies carried out by (Ayan et al., 2006, Mut and Ayan, 2008; 2010; Uysal et al., 2015). Several previous studies were carried out to evaluate the genetic diversity of Orchardgrass genotypes in many different geographic locations, for example (Uysal et al., 2015) has assessed the genetic diversity of Eastern Anatolia region that were collected from natural vegetation of Ağrı, Ardahan, Artvin, Bayburt, Bingöl, Erzurum, Kars and Muş to determine the genotypes available for breeding. Moreover, (Mut and Ayan, 2008) have collected the plants of Orchardgrass from different places of Ondokuzmayıs University Kurupelit campus to determine the genetic diversity among these plants. In addition, (Sagsoz et al., 1996) found differences in terms of morphological and biological characters among the plants of Orchardgrass that were collected from the different regions of Erzurum. As with other studies, Orchardgrass plants were collected from natural flora of Samsun, Sinop and Ordu provinces located in the Middle Black Sea Region (Ayan et al., 2010), While (Madesis et al., 2014) sampled their genotypes from 3 geographically separate locations in north, central, and south Greece.

The most important finding of this study was the highly significant differences $(\mathrm{P}<0.01)$ between studied genotypes for all morphological studied traits (plant height, flag leaf length, flag leaf width, node number per plant, length of the upper internode). This finding is consistent with that of (Madesis et al., 2014) who found significant differences among the studied locations $(\mathrm{P} \leq 0.05)$ for 7 of the 8 morphological traits.

In the present study, the plant heights ranged between 47.43 to $77.57 \mathrm{~cm}$, in other previous studies by (Tosun and Sagoz, 1994; Mika, Kohoutek, and Odstrcilova, 2002; Mut and Ayan, 2008; Aygün et al., 2009; Ayan et al., 2010; Uysal et al., 2015) the plant height were respectively (59.8-64.5 $\mathrm{cm}, 49.1-95 \mathrm{~cm}, 74.7-101.47 \mathrm{~cm}, 63.00-160.00 \mathrm{~cm}, 45.5-114.6 \mathrm{~cm}$, and 70-111cm). In the current study, the flag leaf length of studied plants ranged between $9.00-15.57 \mathrm{~cm}$. Various studies reported between 14.99- $27.40 \mathrm{~cm}, 7.00-20.50 \mathrm{~cm}, 2.00-36.00 \mathrm{~cm}$, and $7.00-26.00 \mathrm{~cm}$, in respective order by (Tosun and Sagoz, 1994; Aygün et al., 2009; Ayan et al., 2010; Uysal et al., 2015). For flag leaf width ranged between 4.21 to 6.93 mm, in previous study (Tosun and Sagoz, 1994; Aygün et al., 2009; Ayan et al., 2010; Uysal et al., 2015) reported different results, respectively were 5- $11 \mathrm{~mm}, 5.18-7.19 \mathrm{~mm}$, 2.70-10.00 $\mathrm{mm}$, and 3.00-5.00 $\mathrm{mm}$. In the current study, the node number per plant ranged between 2.14 to 3 nodes per plant. Several previous results by (Tosun and Sagoz, 1994; Mut and Ayan, 2008; Ayan et al., 2010; Uysal et al., 2015) were consistent with our findings that have shown the nodes number per plant were between (2.7-4.0 nodes per plant, 3-6 nodes per plant, 3-5 nodes per plant, 2-7 nodes per plant). However, our finding is contrary to previous study by (Mut and Ayan, 2008) which have suggested that the node number plant were not significantly different among the genotypes. The current study found that the length of the upper internode was between 9.64 to $17.57 \mathrm{~cm}$. Several studies (Ayan et al., 2010; Uysal et al., 2015) have shown that the length of the upper internode were respectively $1.50-29.30 \mathrm{~cm}$ and, $15-27 \mathrm{~cm}$.

A possible explanation for differences in the morphological traits might be that studied plants were sourced from highly different altitudes. Another possible explanation for this is genetic differences between these studied plants that were obtained from different locations. Furthermore, this differentiation might be attributed to the species mating system, gene flow, genetic drift, long term evolutionary history (Hogbin and Peakall, 1999), habitat differentiation, or management (Peter Schmid et al., 2008). Also, this difference may be explained by the fact that inter location differences may be due to genetic structure of Orchardgrass (Tükel and Hatipoğlu, 1994; Mut and Ayan, 2008).

The current study found that positive significant correlations between the studied morphological traits. This finding is consistent with that of (Tosun, Sagsoz, and Akgun, 1996) who 
found positive and significant correlations between some morphological traits such as hay yield and plant height, leaf length, leaf width.

In the present study, UPGMA dendrogram was drawn to evaluate the morphological traits for Dactylis glomerata and to classify the collected genotypes in different groups. Our current study found Orchardgrass genotypes were divided into 4 groups based on cluster analysis. The genotypes H5, M75 and A121 had the highest value and mean for all morphological studied traits. A possible explanation for this might be that these genotypes have adapted well with the new environment. Also maybe the positive significant correlations between these traits contributed to be this group has the highest value for all studied traits. Similar to previous studies (Aygün et al., 2009; Uysal et al., 2015), they drew UPGMA dendrogram to grouping the collected germplasm. The differences in morphological traits between cluster groups may be explained by the fact that these differences are not caused by environmental conditions (Aygün et al., 2009). Another possible explanation for this may be due to only genetics factor differences between these groups.

In general, Orchardgrass is an important plant due to the fact that it is consumed with appetite by animals. furthermore, Orchardgrass is tolerant to drought, cold, grazing, cutting (Manga, Acar, and Ayan, 2002; Açikgöz, 2008; Ayan et al., 2010;) our results revealed significant variation among studied genotypes for studied traits plant height, flag leaf length, flag leaf width, number of nodes per plant, and the length of the upper internode. This may be considered as an advantage since it provides an opportunity in multipurpose breeding studies. Determination of the genetic diversity of these genotypes with large variations and grouping them accordingly may help in the decision-making process of the breeding line selection phase. Genotypes used in this study were very promising for releasing new cultivars to use in pasture improvement and forage cultivation, where was determined the prominent genotypes for morphological studied traits H5, M75, and A121 were can be used in future breeding programs to develop forage species in Turkey.

\section{Acknowledgements}

This paper was a part of the P.h.D thesis of Ahmad Nabhan "Characterization of Orchardgrass (Dactylis Glomerata L.) Using Morphological Traits And Molecular Markers"

We thank. Prof. Dr. Murat ÜNAL, for helpıng us with collecting the material plants

The first and second authors are supported by the Research Fund of Van Yuzuncu Yil University (grant number FDK-2019-7650).

\section{References}

Açikgöz, E. (2008). Research and Experiment Methods in Agriculture (III. Pres). Ege University Agricultural Faculty Publication, 478.

Anonymous. (2019). Türkiye İstatistik Kurumu 2010. Veritaban1. www.tuik.gov.tr.

Ayan, I., Mut, H., Acar, Z., \& Tongel, M. O. (2006). Determination of some agricultural and cytological characters of natural cocksfoot plants (Dactylis glomerata ssp. glomerata L.). Pakistan Journal of Biological Sciences, 9(12), 2298-2302.

Ayan, I., Mut, H., Asci, O. O., Basaran, U., \& Tongel, O. (2010). Morphological traits of orchard grass accessions in Black Sea Region of Turkey. Options Méditerranéennes-the Contributions of Grasslands to the Conservation of Mediterranean Biodiversity A, 92, 121-124.

Aygün, C., Çakal, Ş., Kara, A., \& Müdürlüğü, A. T. A. E. (2009). Characterization of some coksfoot (Dactylis glomerata L.) lines from the natural rangelands of Eastern Anatolia. Biological Diversity and Conservation, 2(2), 57-64.

Erdoğdu, I., Sever, A. L., Aygün, C., \& Tuna, M. (2018). Eskişehir'de doğal alanlardan toplanan domuz ayrığı (dactylis glomerata l.) populasyonlarında islah yönünden önem taşıyan bazı özelliklerin belirlenmesi. Anadolu Ege Tarımsal Araştırma Enstitüsü Dergisi, 28(1), 45-51.

Garcia, A., \& Lindner, R. (1998). Dactylis glomerata genetic resources: Allozyme frequencies and performance of two subspecies on an acid sandy loam with summer drought. Euphytica, 102(2), 255-264.

Hogbin, P. M., \& Peakall, R. (1999). Evaluation of the contribution of genetic research to the management of the endangered plant Zieria prostrata. Conservation Biology, 13(3), 514-522. 
Jiang, L. F., Zhang, X. Q., Ma, X., Huang, L. K., Xie, W. G., Ma, Y. M., \& Zhao, Y. F. (2013). Identification of Orchardgrass (Dactylis glomerata L.) cultivars by using simple sequence repeat markers. Genetics and Molecular Research: GMR, 12(4), 5111-5123.

Madesis, P., Abraham, E. M., Kalivas, A., Ganopoulos, I., \& Tsaftaris, A. (2014). Genetic diversity and structure of natural Dactylis glomerata L. populations revealed by morphological and microsatellite-based (SSR/ISSR) markers. Genetics and Molecular Research, 13(2), 42264240.

Manga, I., Acar, Z., \& Ayan, I. (2002). Grass Herbage Crops. Ondokuz Mayis University Agricultural Faculty Textlesson, 6, 286.

Mika, V., Kohoutek, A., \& Odstrcilova, V. (2002). Characteristics of important diploid and tetraploid subspecies of Dactylis from point of view of the forage crop production. Rostlinna Vyroba, 48(6), 243-248.

Mut, H., \& Ayan, I. (2008). Determination of Some Morphological and Agricultural Characters of Natural Orchardgrass Plants (Dactylis glomerata ssp. glomerata L.) Collected from Different Places of Ondokuz Mayis University Campus Area, Turkey 1 . Asian Journal of Chemistry, 20(3), 2405.

Ozkose, A., \& Tamkoc, A. (2014). Morphological and agronomic characteristics of perennial ryegrass (Lolium perenne L.) genotypes. Turkish Journal of Field Crops, 19(2), 231-237.

Peng, Y. A. N., Zhang, X., Deng, Y., \& Ma, X. (2008). Evaluation of genetic diversity in wild Orchardgrass (Dactylis glomerata L.) based on AFLP markers. Hereditas, 145(4), 174-181.

Peter-Schmid, M. K. I., Boller, B., \& Kölliker, R. (2008). Habitat and management affect genetic structure of Festuca pratensis but not Lolium multiflorum ecotype populations. Plant Breeding, 127(5), 510-517.

Sagsoz, S., Tosun, M., \& Akgun, I. (1996). Determination of some phenological, morphological and biological characteristics of Orchardgrass (Dactylis glomerata L.) collected from different locations. Turkiye 3. Cayir-Mer'a ve Yembitkileri Kongresi, Erzurum (Turkey), 17-19 Jun 1996.

Sahuquillo, E., \& Lumaret, R. (1999). Chloroplast DNA variation in Dactylis glomerata L. taxa endemic to the Macaronesian islands. Molecular Ecology, 8(11), 1797-1803.

Tosun, M., \& Sagoz, S. (1994). Erzurum yoresinde dogal olarak yetisen domuz ayrigi (Dactylis glomerata spp. hispanica (Roth) Nyman) bitkilerinde bazi morfolojik ve fenolojik ozelliklerin belirlenmesi (Determination of some morphological and phenotypic characters of Orchardgrass Dactyl). Tarla Bitkileri Kongresi, 3, 39-43.

Tosun, M., Sagsoz, S., \& Akgun, I. (1996). Determination of some chemical characters of hay, hay and seed yield of wild orchard grass (Dactylis glomerata L.). Turkey III. Pasture and Forage Congress, 402-407.

Tükel, T., \& Hatipoğlu, R. (1994). Çukurova Bölgesi’nde bulunan doğal domuz ayrığı (Dactylis glomerata L.) bitkisinin morfolojik biyolojik ve tarımsal karakterleri üzerinde araştırmalar. Tarla Bitkileri Kongresi, 3, 25-29.

Tuna, M., Khadka, D. K., Shrestha, M. K., Arumuganathan, K., \& Golan-Goldhirsh, A. (2004). Characterization of natural Orchardgrass (Dactylis glomerata L.) populations of the Thrace Region of Turkey based on ploidy and DNA polymorphisms. Euphytica, 135(1), 39-46.

Uysal, P., Uzun, M., Ozgoz, M. M., Yazici, A., Terzioglu, K., Aksakal, E., Dumlu, S. E., Cakal, S., \& Haliloglu, K. (2015). Morphological and seed yield characteristics of Orchardgrass ecotypes of Eastern Anatolia Region. Ekin Journal of Crop Breeding and Genetics, 1(2), 78-83.

Zhao, X., \& Cheng, Y. (2016). Phylogenetic and Diversity Analysis of Dactylis glomerata Subspecies Using SSR and IT-ISJ Markers. October. 